of National Academy of Educational Sciences of Ukraine, 52-A, Sichovykh Striltsiv Str., Kyiv, Ukraine

\title{
FACILITATIVE SUPPORT OF PROFESSIONAL DEVELOPMENT OF RESEARCH AND TEACHING STAFF IN THE PROCESS OF PREPARING AND HOLDING INTERNATIONAL EDUCATIONAL EXHIBITIONS
}

The article analyses the experience of organizing International Educational Exhibitions in Ukraine in 2016 - 2020. The essence of such concepts as "international educational exhibition", "international educational exhibition space", "facilitative support of professional development of research and teaching staff" is defined. The structural elements of the International Educational Exhibition and the stages of a higher educational institution participation in the exhibition activity (preparatory, direct participation, analysis of the achieved results) are considered. The authors of the article present systematized experience of facilitative support of professional development of research and teaching staff provided by specialists of the Department of Scientific Work of the State Institution of Higher Education "University of Educational Management" of the National Academy of Educational Sciences of Ukraine in the process of preparing, holding and analysing results of International Educational Exhibitions, such as "Innovation in Modern Education", "Modern Educational Institutions", "Education and Career - Student's Day", "Education and Career". The types of organizational and coordination activities are determined, a detailed list of actions of the process of facilitative support by the specialists of the Department of Scientific Work of research and teaching staff as exhibitors and visitors of the exhibition is presented. Methodical structuring and algorithmizing of types of organizational and coordination activities and a detailed list of actions of the facilitation process are described in the following stages: 1) preparation of research and teaching staff (exhibitors and visitors) to participate in International Educational Exhibitions; 2) direct participation of research and teaching staff (exhibitors and visitors) in the International Educational Exhibitions; 3) analysis of the results of participation of research and teaching staff (exhibitors and visitors) in International Educational Exhibitions. The authors have created a classification of events of the International Educational Exhibition according to the congress, competition and exponential components. Statistics of the number of planned and conducted events within the International Educational Exhibition activities in Ukraine in 2016 - 2020 are presented. Emphasis is placed on changing the form of exhibitions from offline to online format due to the COVID-19 pandemic and lockdown (quarantine restrictions) in 2020. Recommendations for higher educational institutions to maintain an integrated information base of exhibition educational activities with detailed information on the activities within the exponential, competitive and congress programs of the exhibition.

Keywords: higher education institution, facilitation support, professional development, research and teaching staff, International Educational Exhibition, international educational exhibition space, exhibition activity, exhibitor, exponential, competitive, congress components of the exhibition program.

Подано до редакиіï 15.11.2020

УДК: 796; 797; 798; 799.

DOI: https://doi.org/10.24195/2414-4665-2020-4-5

Анатолій Чустрак,
кандидат педагогічних наук, доцент,
приват-професор кафедри гімнастики та спортивних єдиноборств,

Державний заклад «Південноукраӥнський національний педагогічний університет імені К. Д. Уиинського», вул. Старопортофранківська, 26, м. Одеса, Украӥна,

Артемій Кізірян, відмінник освіти України, Едвард Кізірян,

студент першого курсу,

Державний заклад «Начіональний університет імені I. І. Мечникова», вул. Дворянська, 2, м. Одеса, Україна

\section{ЩО ЛІПШЕ: ФІЗИЧНА КУЛЬТУРА ЧИ СПОРТ?}

За даними Федерального ичентру лікувальної фізкультури та спортивної медищини Міністерства охорони здоров'я і соиіального розвитку РФ, тільки 12\% людей після заняття спортом високих досягнень залишаються відносно здоровими. У літературі давно ведеться полеміка, щчо краще фізкультура чи спорт. Фізична культура є частиною загальної культури людини. А спорт - ие лише один з багатьох засобів, щчо входять у изю більш загальну категорію «фізична культура». Сьогодні, на жаль, культура заважає жити не тільки спортсменам, 
але і політикам, і бізнесменам, і держчиновникам. У статті звертається увага на негативні сторони спорту, які стали більше виділяться останнім часом: травми, хвороби і навіть смертельні випадки висококваліфікованих спортсменів. У статті наводяться факти, висловлювання відомих вчених, травматологів, лікарів, тренерів про причини негативного впливу спорту та рекомендації, як иъього уникнути. і попереджають: заняття спортом, як і куріння, небезпечно для здоров'я. Подані рекомендачії вчених та лікарів для починаючих спортсменів. Необхідні хоча б консультаиії лікаря та яким видом спорту краще займатися. Які при иььому повинні бути: спортивна одежа, взуття та головне, які навантаження використовувати на початку. Забороняється займатися спортом з діагнозом ракових та імуннодефіичитних хвороб, через простудні та інші запалення $і$ навіть через плохе самопочуття. Потрібно слухати свій організм, закінчувати тренування при перших сигналах втоми та ніколи не перевантажуватись, на щзо рідко звертають увагу тренери. За статистикою травм серед бігунів: найчастіше травмуються коліна, потім гомілкостопи, тазостегнові суглоби, поперек, м'язи і сухожилля, стегна та ікри, верхня частина спини і шия. Американська комісія з безпеки зареєструвала за один рік 554 тисячі травм велосипедистів. Показані рекомендації академіка М. Амосова: комплекс із 10 вправ, повторюючи кожну вправу 100 разів. А тібетські лами рекомендують всього 5 вправ та повторення від 3 до 21 разу кожну. Все можна використовувати на благо, чи на шкоду. Все є ӥжа, і все є отрута, головне - міра. Вибирати Вам - високі спортивні досягнення та рекорди або висока працездатність і здорове довголіття.

Ключові слова: фізична культура, спорт, здоров'я спортсменів ми

\section{Вступ та сучасний стан досліджуваної пробле-}

Фізична культура - це частина загальної культури, яка спрямована на збереження і зміцнення здоров'я людини, в процесі рухової активності. ÏÏ головною метою є формування здорового способу життя, вдосконалення рухової активності та соціальної адаптації шляхом фізичного розвитку фізичного виховання та фізичної підготовки. На відміну від фізичної культури, спорт спрямований на отримання максимального результату і спортивних нагород у вибраному виді спорту. «Спорт (англ. sport, скорочення від старофранцузької desport — «гра», «розвага») — організована за певними правилами змагальна діяльність людей (спортсменів), що полягає в зіставленні їх фізичних та інтелектуальних здібностей, а також підготувка до цієї діяльності.

Спорт насамперед це змагальна діяльність та різні методи підготовки до неї з використанням інтенсивного тренування. Основною метою спорту є отримання морального задоволення від досконалості власних фізичних можливостей, поліпшення особистих абсолютних та групових рекордів, слави та вдосконалення фізико-психічних кондицій людини. Але спорт буває різний. Масовий спорт з регулярними помірними навантаженнями дає можливість мільйонам людей удосконалювати свої фізичні якості та рухові можливості, зміцнювати здоров'я і продовжувати творче довголіття. Більше проблем викликає спорт вищих досягнень та професійний спорт, мета яких досягнення максимально можливих спортивних результатів або перемог на чемпіонатах Європи, світу та Олімпійських іграх.

Сучасний спорт як соціокультурний феномен виступає у багатьох іпостасях: з одного боку, як засіб соціального оздоровлення, як дієвий інструмент відпочинку і відновлення працездатності; $з$ іншого - як засіб психофізичного вдосконалення, як професійну працю; $з$ третього - як видовище, як засіб психоемоційної релаксації (Матвєєв, 1997; Любишева, 2001; Холодов, 2010; Павлов, 2012; Пономарьов, 2016). Тільки рідкісні книги коротко висвітлюють проблеми фізичної культури (Железняк, 2010; Неверкович, 2010).
Мета: звернути увагу на негативні сторони спорту і рекомендації для їх профілактики.

Завдання дослідження: 1. Проаналізувати факти захворювань в різних видах спорту. 2. Виділити негативні сторони спортивної методики тренування. 3. 3'ясувати причини частого ігнорування тренерами рекомендацій лікарів. 4. Привести рекомендації для починаючих спортсменів.

Матеріали і методи дослідження: аналіз спеціальної наукової та методичної літератури в області теорії та методики фізичної культури і спортивного тренування.

Нині добре розроблені питання теорії і методики фізичного виховання і спортивного тренування (Ашмарин, 1990; Визитей, 1990; Матвєєв, 1997; Круцевич, 2000; Кібальнік 2009, Васильєва, 2001; Павлов, 2012 та інші). Вченими розглядаються питання Державної молодіжної політики в сфері соціального здоров'я молоді, підкреслюється цінність здоров'я в середовищі учнівської молоді, пропонуються здоров'язберігаючі моделі професійної соціалізації студентської молоді в умовах соціальної невизначеності (Гафіатуліна 2009; 2012; 2013). Через негативний вплив спорту вчені все більше уваги стали приділяти фізичній культурі (Круцевич, 2000; Кібальнік, 2009; Пономарьов, 2016; Чустрак, Кізірян, 2018).

\section{Результати досліджень}

Чому ж «спортсмени хворіють і вмирають в 2,5 рази частіше, ніж люди $з$ диванів?» (Баррер, 2015).

Нині офіційно налічується вже більше сімдесяти видів спорту, не враховуючи їх підвидів, регіональних і національних різновидів. Тільки Олімпійських видів — 71, і з кожною новою Олімпіадою їх число зростає. Збільшується кількість екстремальних видів спорту. Спорт виділився в самостійну соціальну категорію. Це своєрідна «держава в державі» зі своїми інститутами, вченими, економістами, управлінцями, чиновниками, професійними тренерами, фабриками і цілими загонами обслуговуючих функціонерів, які працюють на перемогу, на максимальні результати, на рекорди. В азарті цієї боротьби часто забувається головне - це здоров'я самих головних учасників цих змагань - спортсменів. Добре, хоч лікарі, все частіше, почали бити на сполох. Статистика: за даними Феде- 
рального центру лікувальної фізкультури та спортивної медицини Міністерства охорони здоров'я і соціального розвитку РФ, лише $12 \%$ людей після заняття спортом високих досягнень залишаються відносно здоровими! Спортсмени вмирають в 2,5 рази частіше, ніж люди 3 диванів» (Баррер, 2015). Лише деякі факти 3 інтернету. «В кінці липня минулого року спортивний світ потрясли смерті в боксі: спершу прийшли важкі новини про Максима Дадашева, потім національна федерація оголосила про втрату Артема Ігнатьєва, а потім стало відомо про смерть кращого суперлегковаговика Аргентини Уго Сантільяни. Трагедії вмістилися в три дні. Російська легкоатлетка померла у 25 років. Їй стало погано на пробіжці. Чемпіон Олімпійських ігор 1980 року у спортивній ходьбі на дистанції 50 км у складі збірної НДР Хартвіг Гаудер помер у віці 65 років. За даними джерела Bild, причиною смерті став серцевий напад, який переніс колишній спортсмен. Двадцятишестирічний Сондре Фоссли тренується у спринтерській групі збірної Норвегії. Він перемагав на Кубку світу і завжди вважався лижником рівня вище середнього. Друге народження Сондре зазначив 13 серпня - він переніс зупинку серця, але вижив дякуючи оперативно і правильно наданої першої допомоги. Минулого літа в 30-річному віці померла лижниця Іда Ейде, яка виступала на Кубку світу; найгучніша смерть - плавець Олександр Дале Оен, який загинув в 2012 році - місяць не дожив до 27 років. У жовтні 2018 року померли 15-річний бігун і стрибун у довжину Дмитро Мартинушкін, а два місяці тому - юний біатлоніст Артемій Хасанкаев. У 2010 році світлою надією збірної був 20-річний лижник Петро Сєдов - багаторазовий чемпіон світу серед юніорів. Петра звозили на Олімпіаду до Ванкувера, дали пробігти там навіть 50 км, а в наступному сезоні він призупинив спортивну діяльність через проблеми 3 серцем (Кукалева, 2019). «Спортсмен завжди перебуває в зоні ризику», - пояснює норвезький кардіолог Ерік Екер Сольберг журналу Dagbladet, підкреслюючи, «що ймовірність померти від серцевої недостатності підвищується в два 3 половиною рази в порівнянні 3 лежачою на дивані людиною». В елітного спортсмена ризик ще вищий: дослідження показали, що серця атлетів мають «збільшені камери і потовщені стінки». «У кращих спортсменів 3 видів на витривалість часто діагностують миготливу аритмію. Те ж відноситься до літніх атлетів з довгою кар'єрою за плечима. Серйозні навантаження на тренуваннях уповільнюють частоту серцевих скорочень». (Раніше нам пояснювали цей факт, як позитивне явище - серце спортсмена за одну систолу (скорочення) викидає в коло кровообігу втричі більше об'єму крові, ніж у не спортсменів, тим самим пояснюючи це економічністю роботи серця). Але фахівці пояснюють: «через таку роботу серце запалюється, що сприяє мерехтінню передньої камери. Також заняття спортом можуть викликати запалення, яке призводить до фіброзу», - заявив фахівець. Фіброз серця, якщо говорити не медичними, а більш зрозумілими термінами - поява рубців на сполучній тканині.

«Олена Мухіна могла стати чемпіонкою на московській Олімпіаді 1980 року, але страшна травма, отримана за кілька тижнів до змагань, кардинально змінила їі життя. На зборі перед Іграми гімнастка вирішила без страховки i тренера виконати складну зв'язку (після перевороту назад - півтора сальто Томаса 3 поворотом на $540^{\circ}$, де приземлення головою вниз), спортсменка «недокрутила», врізалася в поміст головою і зламала шию. До цього вона була лідером збірної СРСР, а після операції 20-річна гімнастка назавжди залишилася паралізованою. Двадцять яскравих років активності, перемог, сподівань і ще 26 повної нерухомості». Її тренер, Михайло Клименко не зважав ні на скарги про самопочуття Олени, ні на травми м'язів, гомілкостопів, вибитих пальців, навіть перелом ноги, вона була змушена тренуватись у гіпсі на одній нозі. А за п'ять років до трагедії Олена травмувала шию. Після невдалого приземлення лікарі констатували «відрив остистих відростків шийного відділу». Олена не могла повернути шию. Не зважаючи на це, Клименко, після обходу лікарів забирав іiі в спортзал, знімав ортопедичний нашийник і вона тренувалась до вечора. Але навіть після страшної травми Олена не осуджала свого тренера, звинувачуючи систему, яка привела до такої трагедії. Всі мовчки спостерігали. Правда після цього «сальто Томаса» було заборонено у жіночій гімнастиці, як заборонили «петлю Корбут» після серії травм. Але спортивна гімнастика продовжує ускладнюватись. Згадайте скорочення «ВОР» - віртуозність, оригінальність і риск, за що судді добавляють гімнастам бали. Цей «ВОР» украв багато здоров'я спортсменів. Страшні історії: травми і падіння на стрибку, прихід на голову при зіскоках 3 колоди, жахливі падіння $з$ елементів на брусах переломи, гіпс, потім контрактури і тривалі періоди відновлення. Але більшість травм у гімнастиці - 65-70 відсотків, не драматичні, вони походять від багаторічного тренувального процесу (Eurosport, 2019). За словами тренера 3 гімнастики і фізіотерапевта Дейва Тіллі (http://shiftmovementscience.com/): «Молоді спортсмени піддаються впливу потужних ударних сил, які можуть перевищувати вагу власного тіла у 8,8-14,9 раз, 1000 раз на місяць і майже цілий рік». Багато Олімпійських чемпіонів закінчують життя хворобами Альцгеймера, Паркінсона, паралічем (Мухамед Алі, Надія Олізаренко, яка в останні роки життя не могла не тільки рухатись, а навіть розмовляти. Вона спілкувалась за допомогою спеціального електронного пристрою, який дозволяє писати $з$ допомогою зору). Департамент у справах ветеранів спорту та Бостонський Університет «Головні висновки: 96 \% професійних гравців в американський футбол страждають хронічною травматичною енцефалопатією; у 87 з 91 мозок мав незворотні дегенеративні зміни!».

\section{Обговорення результатів дослідження}

Який спорт можна вважати безпечним, яка методика підходить підліткам і людям у похилому віці і до чого можуть призвести перевантаження і часті змагання? Найпоширеніша помилка тих, у кого фізичні навантаження від випадку до випадку, та інших, які буквально живуть у спортивному залі, а їх м'язи не встигають відновитися після частих тренувань та необ'єктивної оцінки фізичних навантажень. Травматологи стверджують: «після напівмарафонів та інших забі- 
гів кількість звернень пацієнтів 3 болями в області колінного або тазостегнового суглоба і в стопах збільшується втричі. Це пов'язано з неправильною технікою, невідповідним взуттям, надмірними ударними навантаженнями на суглоби нижніх кінцівок. Для того щоб почати бігати, необхідно підібрати правильний одяг і взуття. Одяг не повинен дозволяти людині, як перегріватися, так і швидко охолонути. Взуття підбирається відносно бігового покриття: ортопедична устілка, яка буде амортизувати, правильно розподілить навантаження на стопу, захистить від болю в стопі і знизить ризик розриву ахіллового сухожилля. Одна 3 найбільш частих причин звернення у відділення травматології та ортопедії - травми під час занять спортом. Наприклад, при діагнозі: пошкодження м'язів і сухожиль, лікування від трьох тижнів, а після цього необхідно час для відновлення та підготовку до занять. Фахівці стверджують: щоб повернутися до колишньої інтенсивності навантажень, після вимушеної перерви, потрібно приблизно 4-6 тижнів. А тренери знають, що за таку перерву можна втратити п'ятирічне досягнення тренованості на витривалість і починати все спочатку. Тому багато спортсменів нехтують цими вимогами, відновлюючи інтенсивні тренування. Слід звернути особливу увагу на медичне обслуговування спортивних залів. Більшість із них працюють навіть без медичних сестер. Спортсмени допускаються на змагання некваліфікованими лікарями. А інколи заявки на змагання просто підробляються тренерами без попереднього огляду спортсменів. Ця тема потребує подальших досліджень. Найбезпечнішим видом спорту вважається плавання. Але плавання не на швидкість і витривалість, а щоб навантажувати і розслабляти м'язи рівномірно. Плавання розслаблює весь опорно-руховий апарат, вдосконалює не тільки м'язи, але і серцево-судинну і дихальну системи, покращує кровопостачання суглобів. Звичайно, i тут $є$ обмеження, коли ви хворієте. Забороняються тренування через простудні або загострені хронічні захворювання і навіть через погане самопочуття. Що важливо зробити перед тим, як почати заняття спортом? Найголовніше - необхідно проконсультуватися 3 лікарем. Слід, як мінімум, зробити електрокардіограму, флюорографію і здати загальний аналіз крові. А якщо є хронічні захворювання, надмірна зайва вага, проблеми 3 диханням або у вашій історії були серйозні травми або операції, перші тренування повинні бути під контролем професіонала, який покаже правильну техніку виконання вправ, складе програму та буде іiі коригувати, згідно стану здоров'я. Для тих, хто все ж нехтує послугами тренера, є одна універсальна порада: ту вагу або ті навантаження, які ви обираєте для себе, варто розділити на три. Нехай тренування будуть повільніші, а їх інтенсивність поступово збільшується з часом. До моменту високих навантажень м'язовий каркас сформується і звикне до тренування, що дозволить уникнути травм (Гафиатулина, 2009). Спорт протипоказаний при онкологічних хворобах, імуннодефіцитних проблемах і при важких формах психічних розладів. Але є хвороби, які неможливо вилікувати без додаткових фізичних вправ. Майже всім пацієнтам, оперованих $з$ приводу травми або ортопедії, в обов'язковому порядку призначається комплекс лікувальної фізкультури. Це не класичні заняття в спортзалі або біг, а цілий комплекс певних вправ, які допомагають поліпшити кровопостачання, пошкоджених суглобів, позбутися контрактури і відновити рухливість. Який спорт краще вибрати людям похилого віку? «У цьому віці не варто займатися спортом, пов'язаним з ударними навантаженнями та додатковою вагою. Це біг, стрибки, контактні види спорту, баскетбол, футбол, бокс, навантаження зі штангою. Також не варто займатися тим спортом, в якому важлива швидка координація рухів: варто віддати перевагу, прогулянкам на велосипеді, спокійному плаванню, аквааеробіці, пілатесу і навіть танцям», але без змагань» (Баррер, 2015). У більшості ми стали працівниками розумової праці, ведемо сидячий спосіб життя i дотримуємося вельми сумнівних харчових звичок. У спробі зберегти своє здоров'я і стрункі фігури ми виходимо на корти і стадіони, працюємо в тренажерних залах, бігаємо на бігових доріжках, крутимо педалі на велосипедах і виснажуємо себе сотнями інших способів. При цьому багато хто з нас, так і 3 тих, хто молодший, доходять до крайнощів. Замість існуючого нині «культу спорту» 3 його принципом «немає болю - немає результату», автор книги «Обережно спорт!», нейрохірург Стівен Баррер, доктор медичних наук, директор Інституту неврології і головний лікар відділення нейрохірургії лікарні Абінгтон Меморіал у Філадельфії, пропонує інші критерії здоровий глузд і помірність. Він попереджає: «що заняття спортом можуть заподіяти шкоду вашому здоров'ю внаслідок навіть найпростіших і легких фізичних вправ. Крім того, серйозну небезпеку таїть у собі «кумулятивний ефект, який може викликати тривале надмірне навантаження на суглоби і м'язи навіть при відсутності травм. Зловживати спортом небезпечно. «Немає болю - немає результату». «Це ствердження зі світу спорту - найбільша дурість з усіх, які я коли небудь чув. А я чув ㄲï із уст людей, які вважаються експертами в області спорту і здорового способу життя. Прихильники цієї ідіотської філософії $\epsilon$ навіть серед докторів наук». Коли інструктор із фітнесу кричить вам з телеекрану: «Примусьте свої м'язи горіти!» - не вірте цьому садисту». «Біль - це сигнал, величезний червоний прапор, яким організм розмахує перед вашим обличчям, попереджаючи про те, що вам потрібно терміново припинити ці дії і дозволити йому відновити завдані збитки». Коли ви перевантажуєте м'язи, в них запускається анаеробний гліколіз. Це фізіологічний стан, коли м'язи, які зазвичай розщеплюють глюкозу із споживанням кисню (аеробний гліколіз), більше не здатні цього робити. В результаті вони розщеплюють глюкозу без споживання кисню. Побічний продукт такого способу виробництва енергії молочна кислота. Накопичуючись у м'язах, вона і викликає хворобливі відчуття тяжкості та іноді судоми словом, все те, що ми вважаємо м'язовою втомою». Оцінки поширеності, пов'язаних із бігом травм, значно варіюються; згідно з деякими, цей параметр досягає 79\%. Одне з досліджень показало, що щорічно від 37 до 56 \% людей, що регулярно займаються бігом, травмуються тим або іншим чином. Кожен рік! Це 
означає, що більшість бігунів щорічно отримують якусь травму, а деякі й по кілька разів за рік. Незважаючи на те, що основне навантаження беруть на себе стопа і гомілковостопний суглоб, найчастіше під час бігу травмуються коліна. На другому місці за схильність до травм стопи і гомілковостопні суглоби (кісточки), за ними слідують тазостегнові суглоби, потім поперек, м'язи і сухожилля, стегна, ікри, верхня частина спини і шия (Баррер, 2015). Якщо ви все ж вирішили зайнятися бігом, перш за все вам потрібно вибрати хороше спортивне взуття, пару кросівок, в яких ваші ноги відчувають себе найбільш комфортно. По можливості бігайте по м'якій поверхні. Багато бігунів вибирають асфальтові доріжки. Але асфальт дуже твердий, влітку гарячий, а взимку слизький. I у нього найвищий «ударний індекс». Доріжки на спортмайданчиках і стадіонах часто мають покриття 3 композитного матеріалу і краще пружинять, знижуючи «індекс навантаження на тіло». Поля та інші природні поверхні ще м'якші, але, як вже було сказано вище, вони таять в собі приховані небезпеки. Поверхні в приміщеннях, якщо вони синтетичні, м'якше вуличних. За даними американської Комісії з безпеки споживчої продукції, у 2009 році американці отримали близько 554 тисячі велосипедних травм. Серед дітей ця цифра становила 300 тисяч травм, 3 яких 15 тисяч випадків вимагали госпіталізації. Травми варіюються від незначних (садна і рани в результаті падіння) до дуже серйозних, особливо при зіткненнях на високій швидкості (важкі черепно-мозкові травми, численні травми і навіть смерть). Також поширені хронічні нетравматичні пошкодження, викликані перевантаженням та положенням велосипедиста під час їзди. Тенденіти, м'язові і суглобові болі - поширені проблеми, пов'язані $з$ повторюваним характером рухів. Компресійна невропатія серединних і ліктьових нервів у руках i статевих нервів пахової області обумовлена положенням тіла під час їзди на велосипеді, а ще одна типова проблема - болі в шийному відділі хребта - пов'язана 3 тим, що велосипедист змушений весь час витягати шию, щоб дивитися вперед. Відомо, що надмірні навантаження приводять до прискореного старіння, зниження захисних сил організму, а також до великих проблем з опорно-руховим апаратом, зокрема, через великий ризик отримання травм і перевантаження кістково-м'язового апарату. Занадто велике навантаження на наш організм призводить до вироблення великої кількості вільних радикалів, при цьому погіршується і метаболічні процеси. А в спекотні дні посилені тренування можуть закінчитися зневодненням. Як правило, проходить не один місяць, перш ніж симптоми перетренованості стають очевидними. При надмірних заняттях спортом в першу чергу порушується режим сну. Насилу прокидаєтеся вранці, можете спати по 12-14 годин, а іноді турбує безсоння. Проявляється емоційна нестійкість, дратівливість і безпричинні напади агресії, часта зміна настрою. Потім настає поступова втрата сил. Звичні спортивні снаряди (гантелі, штанги) стають відчутно важкими, а колишні дистанції пробіжок даються із задишкою і сильною втомою. Через надмірні фізичні навантаження, внаслідок падіння захисних сил організму частіше вини- кають гострі вірусні респіраторні захворювання, а процес одужання триває довше звичайного. Явна ознака перетренованості - втрата ваги (якщо ж, немає зайвої ваги). При виявленні втрати обсягів негайно зменшуйте навантаження, інакше ризикуєте довести себе до повного виснаження. Біг, плавання, лижі - це види спорту, які в першу чергу спонукають до перетренованості. Вони вимагають значних енерговитрат. А також ігрові види спорту, через підвищену емоційність, коли гравці перестають контролювати свій організм. Наприклад, футбол, баскетбол, великий теніс або бадмінтон та інші. Як уникнути перетренованості. В першу чергу навчитися слухати свій організм. Не допускати займатися через силу. Сумнів - це вже привід, щоб зупинитися. Не доводьте себе до втоми. Припиняти тренування слід вже при першій ознаці стомлення. За статистикою, щоб підготувати чемпіона світу або учасника Олімпійських ігор тренеру в середньому потрібно довести до високих результатів тисячу спортсменів. 34 мільйонів спортсменів 269 тисяч вважаються першими, другими і третіми номерами збірних команд різного рівня. Нарешті, тільки 5,5 тисячі осіб змагаються на олімпійському рівні, тобто можуть розраховувати на нечувані гонорари. Виходить, що, відправляючи дитину в спортивну секцію 3 трьох-чотирьох років, Ви можете дати йому маленьку можливість стати багатим і знаменитим, зате відбираєте 9 з 10 шансів залишитися здоровим людиною. Спортивне серце більш досконале, але недовговічне. Щоб забезпечити постійні надмірні навантаження, серце людини змінюється під дією тренувань. Змінене, так зване «спортивне серце» одним скороченням виштовхує в артерії 150-160 мл крові проти 50-60 мл у звичайної людини. Крім того, тренувальний ефект досягається при 180 і більше скорочень у хвилину, i це при тому, що у середнього обивателя 130 ударів виникають тільки в стані панічного страху. Директор Федерального центру спортивної медицини МО3 і СР РФ, професор, доктор наук, заслужений лікар Росії Ігор Іванов зазначає: «Спортивне серце» більш досконале, однак ресурс його невеликий». Серце людини не в змозі одночасно бути «спортивним» і справно працювати протягом, скажімо, 70 років. Через деякий час після завершення регулярного тренувального режиму серце і судини перетворюються в ганчір'я, тому, щоб продовжувати жити нормальним життям, колишні спортсмени змушені до останнього подиху підтримувати себе в стані активності. Відомо, наприклад, що боксер Мохаммед Алі аж до важкого інсульту продовжував щоранку пробігати по 5-10 кілометрів. Однак серцеві проблеми починаються не тільки після закінчення спортивної кар'єри. У результаті дослідження, проведеного в ГУ НЦЗД РАМН під керівництвом професора Полякова, у двох третин юних спортсменів (9-17 років) вже зафіксовані функціональні зміни серцЯ.

3 рекомендацій академіка Миколи Амосова: «Кожен вид тренування має свої плюси і мінуси. Тренувальний ефект для серця найбільший при бігу, але i всі інші види тренування досить ефективні, якщо поставити такий темп, який доводить пульс до 100-120 ударів. Ходьба - найбільш природне навантаження, 
тренувальний ефект визначається відстанню і частотою пульсу. Гімнастиці бракує потужності, зате вона має інші переваги: розробляє суглоби, зміцнює зв'язки i м'язи». Далі академік приводить 10 вправ 3 нахилів, поворотів, підтягувань ніг до живота; зміцнення м'язів живота, сидячи на табуреті 3 закріпленими ногами, присідання, тримаючись за спинку стільця; згинання і розгинання рук в упорі лежачи, руки на дивані і підскоки на одній нозі. «Кожну вправу я роблю в максимально швидкому темпі по сто разів. Весь комплекс займає 25 хвилин. Не всім потрібно стільки рухів, але не менше ніж за 20 робити марно - не буде ефекту. Втягуватися в гімнастику потрібно так само поступово, як і в інші види тренувань. Починати 310 рухів, а потім додавати по 10 кожного тижня (Амосов, 2016)». Східні рекомендації тібетських лам ще більш обережні: кожне $з$ п'яти, ними запропонованих вправ, починати виконувати тільки по три рази і щотижня додавати по два рази. Поступово довести до 21 повторення, і обов'язково виконувати цю гімнастику щодня. А якщо пропустили - починайте спочатку. Якщо робите вправи від випадку до випадку, можете собі тільки нашкодити, смикаючи енергетичну систему то вгору, то вниз.

\section{Висновки}

Багато хто, з не фахівців, помилково вважають, що фізкультура і спорт - це одне і те ж. Різниця фізкультурного та спортивного варіантів занять будьякими фізичними вправами не в тому, які з них робити, а в тому, навіщо і як. Все можна використовувати на благо, чи на шкоду. Все $є$ їжа, і все є отрута, голов-

\section{Література}

1. Академик Николай Амосов о движении и физических упражнениях. Наука и жизнь. Как сохранить здоровье и работоспособность. URL: https://www.nkj.ru/archive/articles/5136/ (дата звернення: 10.07.2020).

2. Ашмарин Б. А. Теория и методики физического воспитания: Учеб. для студентов фак. физ. культуры пед. ин-тов по спец. 03.03 «Физ. культура». Под ред. Б. А. Ашмарина. Москва: Просвещение, 1990. $287 \mathrm{c}$.

$\begin{array}{lll}3 . \text { Баррер Стивен «Осторожно спорт!». } 2015 . \\ \text { c. } & \text { URL: }\end{array}$

https://www.livelib.ru/book/1001226877/quotesostorozhno-sport-o-vrede-bega-fitnesa-i-drugih-

fizicheskih-nagruzok-stiven-barrer\#quotes (дата звернення: 10.07.2020).

4. Васильева О. С., Правдина Л. Р., Литвиненко С. Н. Книга о новой физкультуре. Ростов-на-Дону, 2001. 141 c.

5. Визитей Н. Н. Проблемы методологии построения концепции олимпизма как социальнокультурного явления. Новое мышление и олимпийское движение. Москва, 1990. С. 58-69.

6. Гафиатулина Н. Х. Здоровье как ценность в среде учащейся молодежи: Монография. Ростов-наДону: РАС ЮРГУЭС, 2009. 166 с.

7. Гафиатулина Н. Х. Государственная молодежная политика в сфере социального здоровья молоде- не - міра. Так само і у випадку з фізичними вправами та іграми. Тим більше, що спорт вже давно не тільки змагальна і видовищна, розважальна діяльність, але і підготовка до неї, тобто навчально-тренувальний процес, який зовні дуже схожий на фізкультурний. Але різниця проявляється вже в більш виснажливих тренуваннях. Якщо у фізкультурі заняття спрямовані на виправлення фізичних недоліків, на поліпшення відстаючих якостей і систем, на їх вдосконалення та загальний гармонійний розвиток, то у спортивному тренуванні розвиваються і без того виражені фізичні якості і навички, необхідні для вибраної специфічної діяльності. Причому робиться це за рахунок і на шкоду всім іншим. I не тільки фізичним, але також інтелектуальним та духовним. Все залежить від цілей, які Ви ставите перед собою. Що для Вас важливіше високі спортивні досягнення та рекорди або висока працездатність і здорове довголіття. Особливо небезпечний дитячий спорт, так як підриває життєві сили в найбільш важливий період формування фізичних, інтелектуальних та духовних якостей, відволікає від навчання, дезорієнтує у виборі моральних цінностей. На жаль, не вивчаються питання відстрочених наслідків фізичних і психоемоційних перевантажень у спорті, які переслідують людину все життя. Причому не тільки на фізичному, але й на духовному рівні. У зв'язку 3 цим не зовсім зрозуміла позиція Міністерств охорони здоров'я, які могли б попереджувати, що надмірні заняття спортом, як і куріння, небезпечні для здоров'я.

жи. Вестник развития науки и образования. 2012. №5. C. $110-115$.

8. Гафиатулина Н. Х. Здоровьесберегающие модели профессиональной социализации студенческой молодежи в условиях социальной неопределенности. «Инженерный вестник Дона». 2013. №3. URL: http://www.ivdon.ru/magazine/archive/n3y (дата звернення:14.12. 2020).

9. Кібальник О. Зміст фітнес-технології для підвищення рухової активності підлітків. Фізичне виховання, спорт і культура здоров'я у сучасному суспільстві : зб. наук. пр. Волин. нац. ун-ту ім. Лесі Українки. Луцьк: РВВ “Вежа” Волин. нац. ун-ту ім. Лесі Українки, 2009. № 2 (6). С. 42-46.

10. Круцевич Т. Ю. Управление физическим состоянием подростков в системе физического состояния: автореф. дис. ... д-ра наук по физ. воспитанию и спорту: 24.00.02. Нац. ун-т физ. воспитания и спорта Украины. Киев, 2000. 44 с.

11. Лубышева Л. И. Социальная роль спорта в развитии общества и социализации личности. Теория и практика физической культуры. 2001. №4. С. 11 15.

12. Матвеев Л. П. Общая теория спорта. Москва, 1997. $304 \mathrm{c}$.

13. Павлов Е. В. Социокультурный феномен спорта: коммуникативный аспект: автореферат дис. ... канд. филос. наук: 23.00.02. Томск, 2012.

14. Пономарев И. Е., Литвинов В. А., Пономарев О. И. Состояние общества, здоровье человека и про- 
блемы воспитания, образования и оздоровления студентов средствами физической культуры. Гуманитарные, социально-экономические и общественные науки. 2016. №4.

15. Холодов, Ж. К., Кузнецов В. С. Теория и методика физического воспитания и спорта: учеб. пособие для студ. высш. учеб. заведений. 8-е изд., стер. Москва: Академия, 2010. 480 с.

16. Педагогика физической культуры и спорта : учебник для студ. высш. учеб. заведений. С. Д. Неверкович [и др.]; под ред. С. Д. Неверковича. Москва: Академия, 2010. 336 с.

17. Теория и методика обучения предмету «Физическая культура»: учеб. Пособие я студ. высш. учеб. заведений. Ю. Д. Железняк [и др.]; под ред. Ю. Д. Железняка. 4-е изд., перераб. Москва: Академия, 2010. $272 \mathrm{c}$.

18. Почему умирают спортсмены. Валерия Кукалева. URL: https://www.eurosport.ru/allsports/story_sto7428174.shtml (дата звернення: 10.07.2020)

19. Травмы в гимнастике. URL: //https://www.flogymnastics. com/articles/6275076-5-ofthe-most-common-gymnastics-injuries-how-best-toprevent-them (Eurosport, дата звернення: 10.07.2020).

20. Чустрак А. П., Кизирян А. Г., Кизирян С. Д. Оздоровлене людей среднего и старшего возравста с применением упражнений ударно-волнового воздействия. Матеріали ХII міжнародної науковопрактичної конферениіі 13-14 вересня 2018 року. Одеса. Ч. 2. С. 101-105.

21. Чустрак А. П., Кизирян А. Г., Кизирян С. Д. Оздоровительный комплекс упражнений с использованием большого гимнастического мяча (фітбола). Матеріали ХII міжнародної науково-практичної конферениії 13-14 вересня 2018 року. Одеса. Ч. 2. C. $106-109$.

\section{References}

1. Akademyk Nykolai Amosov o dvizhenii $i$ fizycheskikh uprazhneniiakh. Nauka $i$ zhyzn. Kak sokhranit zdorovie $i$ rabotosposobnost. [Academician Nikolai Amosov about movement and exercise. Science and life. How to maintain health and performance]. Retrieved from https://www.nkj.ru/archive/articles/5136/ [in Russian].

2. Ashmarin, B. A., Vinohradov, Yu. A., Viatkina, 3. N. and all. (1990). Teoryia i metodyka fizicheskoho vospytanyia [Theory and methods of physical education]. B. A. Ashmarina (Eds.). Moscow: Prosveshchenye [in Russian].

3. Barrer Stiven (2015). «Ostorozhno sport!» [Caution sport!]. Retrieved from https://www.livelib.ru/book/1001226877/quotesostorozhno-sport-o-vrede-bega-fitnesa-i-drugihfizicheskih-nagruzok-stiven-barrer\#quotes [in Russian],

4. Vasileva, O. S., Pravdina, L. R., Litvynenko, S. N. (2001). Kniha o novoi fizkulture [Book about a new physical education]. Rostov-on-Don [in Russian].

5. Vizytei, N. N. (1990). Problemy metodolohii postroenyia kontseptsii olimpyzma kak sotsialnokulturnoho yavleniia [Problems of the methodology of constructing the concept of Olympism as a socio-cultural phenomenon]. Novoe myshlenie $i$ olimpyiskoe dvyzhenye - New thinking and the Olympic movement. Moscow [in Russian].

6. Hafiatulina, N. Kh. (2009). Zdorovie kak tsennost $v$ srede uchashcheisia molodezhi [Health as a Value Among Students]. Rostov-on-Don: RAS YuRHUЭS [in Russian].

7. Hafiatulina, N. Kh. (2012). Hosudarstvennaia molodezhnaia politika $\mathrm{v}$ sfere sotsialnoho zdorovia molodezhi [State youth policy in the field of youth social health]. Vestnyk razvytyia nauky y obrazovanyia - Bulletin of the development of science and education, 5, 110 115 [in Russian],

8. Hafiatulina, N. Kh.

(2013). Zdorovesberehaiushchie modeli professyonalnoi sotsializatsii studencheskoi molodezhi $\mathrm{v}$ uslovyiakh sotsyalnoi neopredelennosti [Health-saving models of professional socialization of student youth in conditions of social uncertainty]. "Ynzhenernyi vestnyk Dona» "Engineering Bulletin of the Don", №3. Retrieved from http://www.ivdon.ru/magazine/archive/n3y [in Russian],

9. Kibalnyk, O. (2009). Zmist fitnes-tekhnolohii dlia pidvyshchennia rukhovoi aktyvnosti pidlitkiv [The content of fitness technology to increase motor activity of adolescents]. Fizychne vykhovannia, sport $i$ kultura zdorovia u suchasnomu suspilstvi: zb. nauk. pr. Physical education, sports and health culture in modern society: a collection of scientific papers, № 2 (6). Lutsk: $R V V$ «Vezha» Volyn. nats. un-tu im. Lesi Ukrainky [in Ukrainian].

10. Krutsevych, T. Yu. (2000). Upravlenie fizicheskim sostoianiem podrostkov $\mathrm{V}$ sisteme fizicheskoho sostoianiia [Management of the physical condition of adolescents in the system of physical condition]. Extended abstract of Doctor's thesis. Kiev [in Russian].

11. Lubysheva, L. Y. (2001). Sotsialnaia rol sporta v razvitii obshchestva y sotsializatsii lichnosti [The social role of sport in the development of society and ihe socialization of the individual]. Teoryiai $i$ prakiyka fizicheskoi kultury - Theory and practice of physical culture, №4 [in Russian].

12. Matveev, L. P. (1997). Obshchaia teoriia sporta [The general theory of sports]. Moscow [in Russian].

13. Pavlov, E. V. (2012). Sotsiokulturnyi fenomen sporta: kommunikativnyi aspekt [The sociocultural phenomenon of sports: the communicative aspect]. Extended abstract of candidate's thesis. Tomsk [in Russian].

14. Ponomarev, Y. E., Litvinov, V. A., Ponomarev, O. Y. (2016). Sostoianie obshchestva, zdorovie cheloveka i problemy vospitanyia, obrazovaniia i ozdorovleniia studentov sredstvami fizicheskoi kultury [The state of society, human health and the problems of education, education and health of students by means of phisical education]. Humanytarnyie, sotsialno-ekonomicheskie $i$ obshchestvennye nauki-Humanitarian, socio-economic and social sciences, 4 [in Russian].

15. Kholodov, Zh. K. Kuznetsov, V S. (2010). Teoriia $i$ metodyka fyzycheskoho vospytanyia $i$ sporta [Theory and methodology of physical education and sports] (8 ed.). Moscow: Akademiia [in Russian]. 
16. Neverkovich, S. D. (2010). Pedahohika fizycheskoi kultury $i$ sporta. [Pedagogy of physical education and sport]. S. D. Neverkovicha (Eds.). Moscow: Akademiia [in Russian].

17. Zhelezniak, Yu. D. (2010). Teoriia i metodika obucheniia predmetu «Fizicheskaia kultura» [Theory and methodology of teaching the subject «Physical Culture»] ( $4^{\text {th }}$ ed. rev.). Yu.D. Zhelezniaka (Eds.). Moscow: Akademyia [in Russian].

18. Pochemu umiraiut sportsmeny [Why do athletes die]. Retrieved from https://www.eurosport.ru/allsports/story_sto7428174.shtml. [in Russian].

19. Travmy v himnastike [Gymnastics Injuries]. Retrieved https://www.flogymnastics.com/articles/6275076-5-of- the-most-common-gymnastics-injuries-how-best-toprevent-them. [in Russian].

20. Chustrak, A. P., Kyzyrian, A. H., Kyzyrian, Ye. D.(2018). Ozdorovlenie liudei sredneho i starsheho vozravsta s primenieniem uprazhnenii udarno-volnovoho vozdeistviia [Improving the health of people of middle and older age with the use of shock-wave exercises]. Proceedings of XII International, scientific-practical conference, part 2. Odesa [in Russian].

21. Chustrak, A. P., Kyzyrian, A. H., Kyzyrian, E. D. (2018). Ozdorovitelnyi kompleks uprazhnenii s ispolzovaniem bolshoho himnasticheskoho miacha (fitbola) [Wellness complex of exercises using a large gymnastic ball (fitball)]. Proceedings of XII International, scientific-practical conference, part 2. Odesa [in Russian].

Anatoliy Chustrak,

PhD (Candidate of Pedagogical Sciences), associate professor, Privat-professor of the Department of Gymnastics and Martial Arts, The State Institution "South Ukrainian National Pedagogical University named after K. D. Ushynsky", 26, Staroportofrankivska Str., Odessa, Ukraine, Artemy Kiziryan, high achiever of education of Ukraine, Edward Kiziryan, first-year student,

The State Institution "I.I. Mechnikov National University", 2, Dvoryanska Str., Odessa, Ukraine

\section{WHICH IS BETTER: PHYSICAL EDUCATION OR SPORTS?}

According to the Federal center of kinesitherapy and sports medicine of the Ministry of Health and Social Development of the Russian Federation, only $12 \%$ of people who are involved in sports become apparently healthy. There has long been a polemic in literature, which is better physical education or sports? Physical culture is a part of General human culture. And the sport is just one of many means of physical exercise within this more General category of «physical culture». Today, unfortunately, culture prevents to live not only for athletes, but also politicians, businessmen and government officials. The article draws attentions to the negative aspects of sports that have become more prominent in recent years: injury, illness and even deaths of elite athletes. The article provides facts, statements of famous scientists, traumatologists, doctors and trainers about the reasons for the negative impact of sports and recommendations how to avoid it and warn that exercise: sports like smoking are dangerous to health. Recommendations for beginner athletes are given. The doctor's consultation and recommendations what kind of sport is best to do need to be at least in this problem. What should be: sportswear, shoes and most importantly what loads to use in the beginning. It is forbidden to go in for sports with a diagnosis of cancer and immunodeficiency diseases, colds and other inflammations and even if you feel ill. You need to listen to your body, finish training at the first signs of fatigue and avoid strenuous physical activity, which is rarely noticed by coaches. According to the statistics of injuries among runners: the most common injuries are knees, then ankles, hips, lower back, muscles and tendons, thighs and calves, upper back and neck. The US Safety Commission has registered 554,000 injuries to cyclists in one year. The recommendations of Academician M. Amosov are shown: a set of 10 exercises, repeating each exercise 100 times. Tibetan lamas recommend only 5 exercises and repetitions from 3 to 21 times each of the exercise. Everything can be used for good or harm. Everything is food, and everything is poison, the main thing is moderation. You can choose high sports achievements and records or high efficiency and healthy longevity.

Keywords: physical education, sports, health of athletes.

Подано до редакиії 17.11.2020 